\title{
Central canal enhancement and the trident sign in spinal cord sarcoidosis
}

Figure 1 Sagittal MRI shows central canal enhancement in spinal cord sarcoidosis
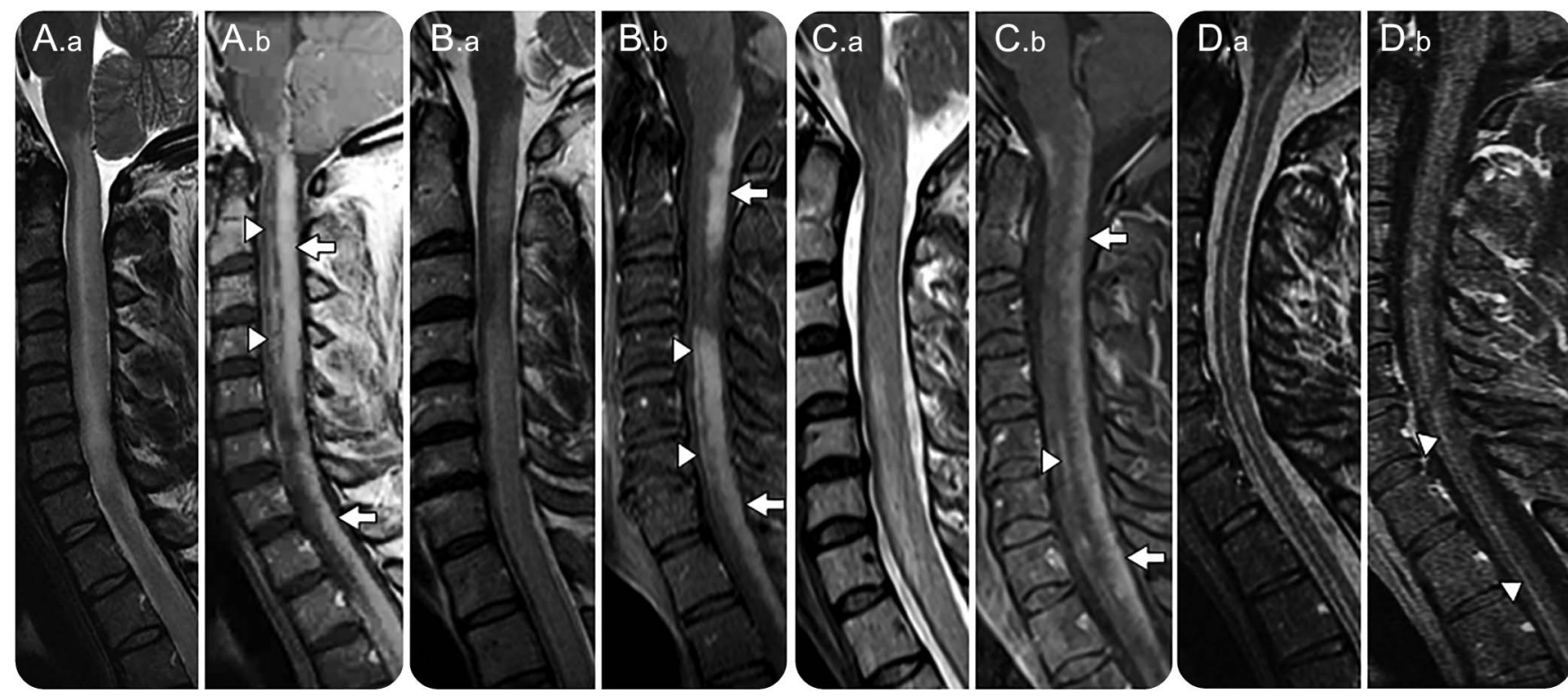

MRIs show longitudinally extensive T2 hyperintensity (A.a, B.a, C.a, D.a) with dorsal subpial enhancement (A.b, B.b, C.b; arrows) and central canal enhancement (A.b, B.b, C.b, D.b; arrowheads).

We report an enhancement pattern in 9 patients with spinal cord sarcoidosis (SCS) with subacute onset $(<4$ weeks) myelitis as the initial manifestation of sarcoidosis. Presenting symptoms included numbness in 9, urinary complaints in 7 , and weakness in 6 . Examination revealed abnormal proprioception in 8 , spastic quadriparesis/paraparesis in 6, and sensory level in 6. MRI showed central canal enhancement alone (11\%) or in combination with dorsal-subpial enhancement ${ }^{1}(89 \%)$ (figure 1), often resembling a trident head on axial sequences (figure 2). Lung biopsies in 7 patients confirmed sarcoidosis; both patients without biopsies had hilar adenopathy. Central canal enhancement and the trident sign in subacute myelitis should raise suspicion for SCS.

Nicholas L. Zalewski, MD, Karl N. Krecke, MD, Brian G. Weinshenker, MD, Allen J. Aksamit, MD, Brittani L. Conway, MD, Andrew McKeon, MD, Eoin P. Flanagan, MBBCh

From the Mayo Clinic, Rochester, MN.

Author contributions: Nicholas Zalewski: lead author, data acquisition. Karl Krecke: radiographic data review. Brian Weinshenker: critical revision of manuscript, analysis and interpretation. Allen Aksamit: critical revision of manuscript, analysis and interpretation. Brittani Conway: data acquisition. Andrew McKeon: critical revision of manuscript, analysis and interpretation. Eoin Flanagan: study and concept design, analysis and interpretation, critical revision of manuscript, study supervision.

Study funding: No targeted funding reported.

Disclosure: N. Zalewski and K. Krecke have no disclosures. B. Weinshenker receives royalties from RSR and Oxford University for technology license for aquaporin-4 autoantibodies used for diagnosis of neuromyelitis optica. He serves on data safety monitoring committees for Novartis, Biogen-Idec, and Mitsubishi pharmaceutical companies, and serves on an adjudication panel for Medimmune Pharmaceuticals. He served as a consultant for GlaxoSmithKline, Elan, Ono, Chugai, and Alexion and Novartis pharmaceutical companies. He serves on editorial boards for Neurology ${ }^{\circledR}$, the Canadian Journal of Neurologic Sciences, and Turkish Journal of Neurology. A. Aksamit and B. Conway have no disclosures. A. McKeon has received research support from Medimmune and has served as a consultant for Medimmune (without personal compensation). E. Flanagan has no disclosures. Go to Neurology. org for full disclosures.

Correspondence to E.P. Flanagan: flanagan.eoin@mayo.edu 
Figure 2 Axial postgadolinium images highlight the trident sign
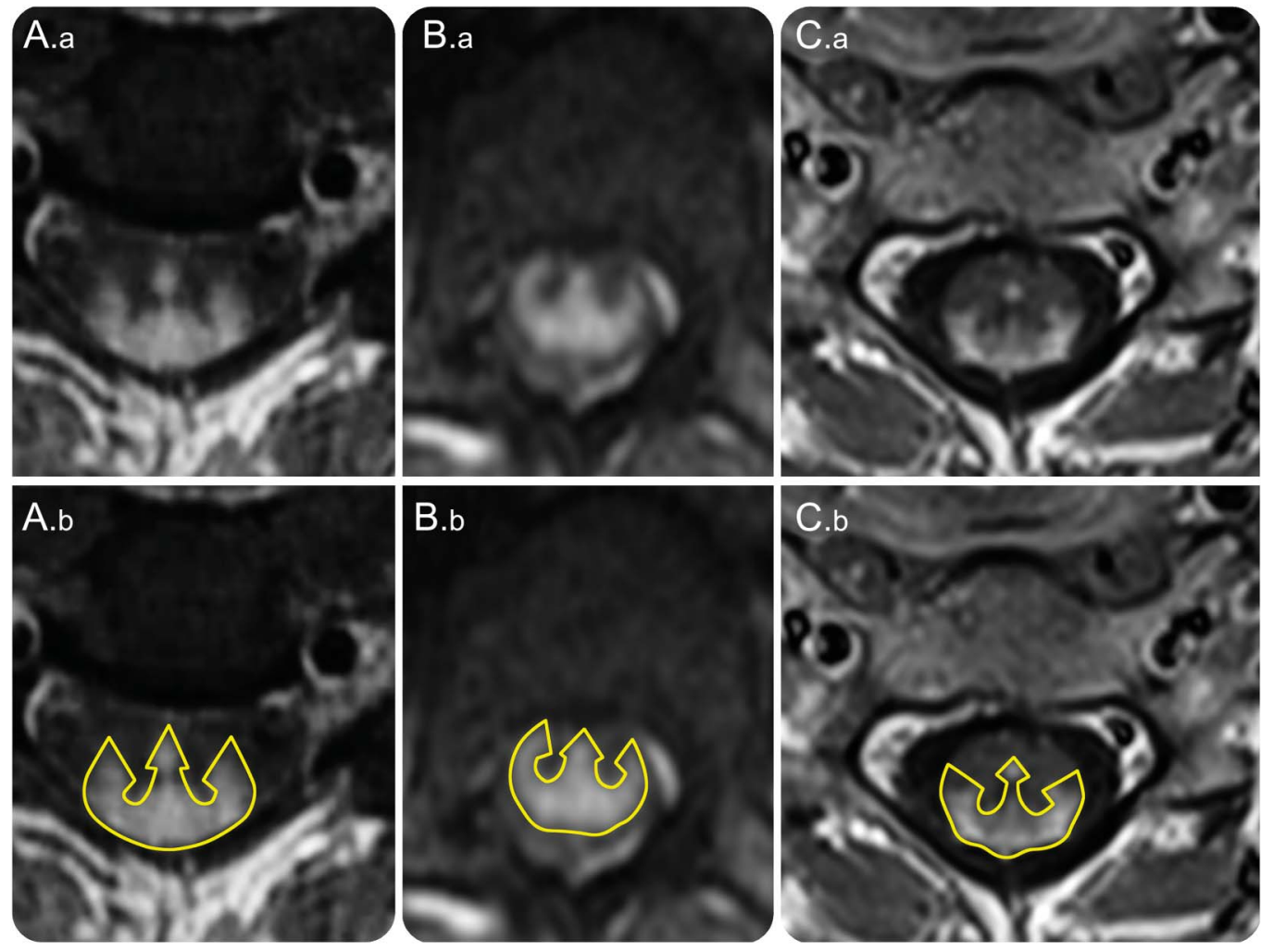

Crescent-shaped layering of posterior subpial enhancement accompanied by central canal enhancement led to a 3-pronged appearance (A.a, B.a, C.a) resembling a trident head (A.b, B.b, C.b).

1. Flanagan EP, Kaufmann TJ, Krecke KN, et al. Discriminating long myelitis of neuromyelitis optica from sarcoidosis. Ann Neurol 2016;79:437-447.

\section{WriteClick ${ }^{\circledR}$ rapid online correspondence}

The editors encourage comments about recent articles through WriteClick:

Go to Neurology.org and click on the "WriteClick" tab at the top of the page. Responses will be posted within 72 hours of submission.

Before using WriteClick, remember the following:

- WriteClick is restricted to comments about studies published in Neurology within the last eight weeks

- Read previously posted comments; redundant comments will not be posted

- Your submission must be 200 words or less and have a maximum of five references; reference one must be the article on which you are commenting

- You can include a maximum of five authors (including yourself) 


\section{Neurology}

\section{Central canal enhancement and the trident sign in spinal cord sarcoidosis Nicholas L. Zalewski, Karl N. Krecke, Brian G. Weinshenker, et al. Neurology 2016;87;743-744 \\ DOI 10.1212/WNL.0000000000002992}

This information is current as of August 15, 2016

\section{Updated Information \& Services}

References

Citations

Subspecialty Collections

Permissions \& Licensing

Reprints including high resolution figures, can be found at: http://n.neurology.org/content/87/7/743.full

This article cites 1 articles, 0 of which you can access for free at: http://n.neurology.org/content/87/7/743.full\#ref-list-1

This article has been cited by 7 HighWire-hosted articles: http://n.neurology.org/content/87/7/743.full\#\#otherarticles

This article, along with others on similar topics, appears in the following collection(s):

All Spinal Cord

http://n.neurology.org/cgi/collection/all_spinal_cord

Autoimmune diseases

http://n.neurology.org/cgi/collection/autoimmune_diseases

Transverse myelitis

http://n.neurology.org/cgi/collection/transverse_myelitis

Information about reproducing this article in parts (figures,tables) or in its entirety can be found online at:

http://www.neurology.org/about/about_the_journal\#permissions

Information about ordering reprints can be found online:

http://n.neurology.org/subscribers/advertise

Neurology ${ }^{\circledR}$ is the official journal of the American Academy of Neurology. Published continuously since 1951, it is now a weekly with 48 issues per year. Copyright (O 2016 American Academy of Neurology. All rights reserved. Print ISSN: 0028-3878. Online ISSN: 1526-632X.

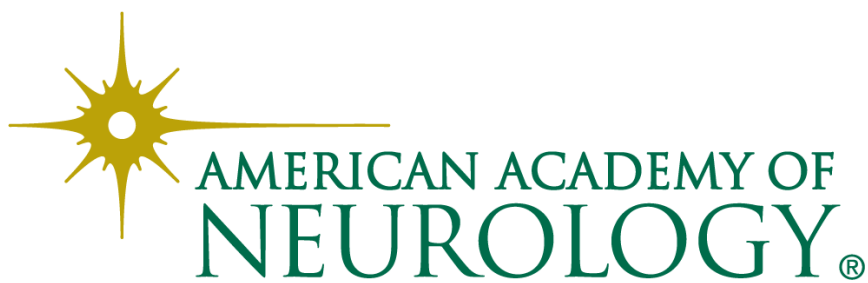

